\title{
Didactic Engineering to Teach Leonardo Sequence: A Study on a Complexification Process in a Mathematics Teaching Degree Course
}

\author{
Francisco Regis Vieira Alves ${ }^{1,2 *}\left(\right.$ ) Milena Carolina dos Santos Mangueira ${ }^{1,3}\left({ }^{\circledR}\right.$, Paula Maria Machado Cruz Catarino ${ }^{4}\left({ }^{-}\right.$ \\ Renata Passos Machado Vieira ${ }^{1}[$
}

${ }^{1}$ Instituto Federal de Educação, Ciência e Tecnologia do Estado do Ceará - IFCE, BRAZIL

${ }^{2}$ Bolsista de Produtividade do Conselho Nacional de Desenvolvimento Científico e Tecnológico - CNPq - PQ2, BRAZIL

${ }^{3}$ Bosista pelo Conselho Nacional de Desenvolvimento Científico e Tecnológico (CNPq), BRAZIL

Universidade de Trás-os-Montes e Alto Douro - UTAD, PORTUGAL

*Corresponding Author: fregis@ifce.edu.br

Citation: Alves, F. R. V., Mangueira, M. C. d. S., Catarino, P. M. M. C., \& Vieira, R. P. M. (2021). Didactic Engineering to Teach Leonardo Sequence: A Study on a Complexification Process in a Mathematics Teaching Degree Course. International Electronic Journal of Mathematics Education, 16(3), em0655. https://doi.org/10.29333/iejme/11196

\section{ARTICLE INFO}

Received: 8 Apr. 2021

Accepted: 6 Aug. 2021

\begin{abstract}
This paper presents a study based on didactic engineering and the theory of didactical situations on the complexification of the Leonardo sequence, addressing its numbers in a two-dimensional way, with the insertion of the imaginary unit $i$. This study is an excerpt from a masters' thesis research done in the postgraduate programme in science and mathematics teaching of the Federal Institute of Ceará. It was conducted via Google Meet in an initial teacher education class in History of Mathematics. We will present a problem situation based on the research and the teaching methodologies assumed in it to evaluate the students' investigative and intuitive side faced with the situation presented. We assessed the results according to the methodologies used and carried out an internal validation. Thus, we concluded that the students could build their knowledge themselves, becoming protagonists of this construction and obtaining an evolutionary understanding of the Leonardo sequence.
\end{abstract}

Keywords: didactic engineering, theory of didactical situations, history of mathematics, Leonardo sequence, complexification

\section{INTRODUCTION}

The teaching of linear and recurrent sequences has become increasingly frequent in papers published in journals on mathematics education and mathematics teaching (Alves et al., 2019; Oliveira et al., 2018; Slisko, 2020). Thus, we highlight the use of didactical teaching situations to transform a given object of mathematical study that often appears only in articles of pure mathematics, into content to teach.

Given this, much has been questioned about methodological alternatives that can be taken to the classroom, fostering a better understanding of mathematical contents. According to Rodrigues and Alves (2019), learning by using daily situations and appropriate teaching materials instigate students in the teaching and learning process, making them more receptive to new knowledge.

Although the Leonardo sequence is linear and recurrent, similar to the Fibonacci sequence, there are few publications about Leonardo numbers in the literature, either in pure mathematics or teaching.

From this problem, we chose the Leonardo sequence as the object of mathematical study, thus emphasising its complexification process. We also used the research methodology of didactic engineering, with its French aspects, and the teaching methodology of the theory of didactical situations to complement the analysis of the didactic teaching situations posed.

After delimiting the problem, we outlined the guiding question of the research: How to describe teaching situations involving the Leonardo sequence's complexification process? Thus, we defined the general objective, i.e., to develop the complexification process of the Leonardo sequence through proposing teaching didactical situations based on the didactic engineering associated with the theory of didactical situations.

Finally, we carry out the analysis of our object, based on didactical engineering in association with the theory of didactical situations, describing its phases. In the following sections, we apply this methodology within an undergraduate mathematics teaching degree course at the Federal Institute of Education, Science and Technology of the State of Ceará (IFCE), in a History of Mathematics class. 


\section{PRELIMINARY ANALYSIS}

This section develops the first phase of the research methodology used in this work, known as didactic engineering, structured in four phases and associated with the theory of didactical situations. The teaching methodology arises to substantiate the problem situation posed in this study, structured in four stages (action, formulation, validation, and institutionalisation), to subsidise a modelling for a teaching practice to expose mathematical content that allows the student a better understanding of mathematical learning. Such methodologies will be discussed in later sections.

A bibliographical survey must be carried out on the mathematical content related to the complexification process of the Leonardo sequence, emphasising two-dimensional relationships. For this, the teacher must consider the general objective of the research, highlighting the possible obstacles that he/she may meet in the workplace, circumventing them in advance so that the experimentation and the students' learning process are successful.

The works by Almouloud and Silva (2012), Almouloud and Coutinho (2008), Artigue (1995), Alves and Dias (2017), Brousseau (1986), Almouloud (2007), and Vieira et al. (2019b) are the most relevant for the study of research and teaching methodology. Regarding the object of mathematical study, we have Catarino and Borges (2019), Alves and Vieira (2020), Vieira et al. (2019a), Shannon (2019) and Vieira et al. (2020). To construct the epistemic mathematical field, we can highlight the works by Harman (1981), Oliveira (2018), Oliveira et al. (2017), and Vieira et al. (2019a) for the process of complexification of recursive linear sequences. Regarding Leonardo sequence, we present Catarino and Borges (2019), Alves and Vieira (2020), Vieira et al. (2019a), Shannon (2019), and Vieira, Mangueira, Alves, and Catarino (2020).

The works by Artigue (1995), Pommer (2013), Alves and Dias (2017), Almouloud and Silva (2012), Almouloud and Coutinho (2008), and Brousseau (1986) can be highlighted for the research methodology didactic engineering. Regarding teaching theory, the theory of didactical situations, we cite Brousseau (1986), Almouloud (2007), Vieira et al. (2019b), and Alves et al. (2019).

\section{DIDACTIC ENGINEERING}

In this work, we used the research methodology called didactic engineering, outlined and structured in the perception of this methodology. Initially studied by Artigue (1995) in the 1980s, this methodology has its origin in France, after numerous discussions regarding the didactics of mathematics (Pommer, 2013). Artigue (1995) also compares this technique with an engineer's work, needing first to construct logical reasoning based on scientific knowledge to be worked later with the most complex objects.

Didactic engineering allows the teacher, through an investigation, to anticipate the possible obstacles and difficulties of a teaching situation. Alves and Dias (2017) also report that this methodology "was used to designate/involve a modus operandi of investigation or as a methodology for the analysis of didactic situations". Given this, this methodology is divided into four phases: preliminary analysis or previous analysis, conception and a priori analysis, experimentation and validation, and a posteriori analysis.

The previous or preliminary analysis consists of the bibliographical study, with the development of the epistemic mathematical field of the object of study. Thus, mathematical definitions are carried out and explored in didactical teaching situations. Almouloud and Silva (2012) say that at this stage, an "epistemological analysis of current teaching and its effects, students' conceptions, difficulties and obstacles, and an analysis of the field of restrictions and requirements in which the effective didactic realisation will be situated" is done.

During this phase, the teacher/researcher may be based on several factors, according to the experience of a given teaching situation. Surveys of those obstacles are relevant to student learning evolution, enabling the construction of a good teaching situation.

In the second phase, a priori conception and analysis, the variables, which may be microdidactic, as to the process of organising the research locally, or macrodidactic, as to the overall organisation of the research, must be chosen. Based on Almouloud and Silva (2012), some points should be taken into account during this phase, such as

Describe the choices made at the local level (occasionally relating them to the global selections) and the characteristics of the adidactic situation developed; Analyse what could be at stake in this situation for the student, depending on the possibilities of action, selection, decision, control, and validation that the student will have during the experiment; Predict fields of possible behaviours and try to demonstrate how the analysis allows controlling their meanings and ensure, particularly, that if such expected behaviours occurred, it is as a consequence of the development targeted by learning. ( $p$. 27)

The objective of this second phase, according to Almouloud and Coutinho (2008, p. 67), "[...] is to determine how the choices made (the variables we want to assume as pertinent) allow us to control the students' behaviours and explain their meaning." Thus, based on the development of the epistemic-mathematical field, some didactical teaching situations are chosen, based on the students' previous knowledge.

In the third phase, experimentation, the didactic teaching situations elaborated in the previous phase are applied, and the objectives and conditions for the research should be verified as to whether they are according to the parameters. The data must be registered during experimentation to be analysed and discussed in the next phase. For data analysis, a teaching methodology must be used - the theory of didactical situations-, which will be discussed in the following section. 
In fact, in this phase, the didactic contract can occur. This contract, according to Brousseau (1986), is an agreement made between the teacher and student involved in the execution of the didactical situation. In experimentation, the didactical situations developed are put into practice, allowing for the construction of student's knowledge with the least teacher's interference. For this, alternatives and tools are offered to help students in this journey, their previous knowledge discussed in the epistemicmathematical field.

The last phase, the a posteriori analysis and validation, is when the data collected during the previous step are discussed and analysed. This analysis can be done through photo registers, interviews, and audio and video recordings (Artigue, 1995). This analysis includes confronting this phase with the a priori analysis phase, thus validating the hypotheses raised during the research. This validation will take place internally or externally. The external validation occurs by comparing the places where didactic situations were applied using didactic engineering, with other places where this methodology was not used. In the internal validation, only the place where the didactic engineering was applied is analysed.

\section{THEORY OF DIDACTICAL SITUATIONS}

To investigate a classroom around the object of study, we used the teaching methodology based on the theory of didactical situations. This methodology models a specific mathematical content to facilitate its exposition to the students during the teaching practice to achieve a successful teaching and learning process and the students' knowledge evolution.

The theory of didactical situations is a teaching methodology studied by Brousseau (1986), aiming to investigate didactical teaching situations and the interactions between students and teachers (Almouloud, 2007). To analyse these didactic teaching situations, some questions, called problem situations, are posed through activities, which are then analysed based on their four phases: action, formulation, validation, and institutionalisation.

In the action situation, a teaching situation is presented to the students, so they seek ways to reach the problem resolution in their previous knowledge. Students are expected to commit to this activity proposed, performing some actions of a more immediate nature (Vieira et al., 2019b).

In the formulation situation, the main objective is that two or more students exchange information through written or oral messages, in natural language, or mathematics. During this time, the students can create more elaborate theoretical models. At this stage, the students clarify their actions during the solutions they found (Alves et al., 2019).

In the validation situation, the students must then demonstrate that the model they created is valid, seeking more accurate justifications, such as explanation, proof, or demonstration, which makes their model pertinent to the group in which they are inserted. It is also interesting to explain the solutions and demonstrations to all students and the teacher involved to debate the solutions obtained, aiming to build knowledge (Brousseau, 1986).

In the situation of institutionalisation, the intentions and objectives of the activities proposed, referred to as problem situations, are disclosed. The teacher then fixes conventionally and explicitly the cognitive status of knowledge, intermediating the transposition of knowledge from the individual plane to the dimension of scientific knowledge (Almouloud, 2007).

According to Vieira et al. (2019b), it is important that "during the situations debated, students can discuss the wrong solutions of the activity proposed, because thus they can perceive where they are going wrong, reaching the correct resolution more easily." Based on the methodologies discussed, the epistemic-mathematical field is then constructed, applying the phases of didactic engineering and the theory of didactical situations.

\section{EPISTHEMIC-MATHEMATIC FIELD}

Some bibliographic research was done for the investigation of the complexification process of the Leonardo sequence. The Leonardo sequence is very similar to the Fibonacci sequence, differing only its initial values and the addition of value 1 in Leonardo sequence recurrence. This sequence was initially presented by Catarino and Borges (2019) and has been studied by Alves and Vieira (2020), Vieira et al. (2019a), Shannon (2019), and Vieira et al. (2020), who present a mathematical evolution of this sequence. Historically, this sequence is little known. Alves et al. (2020) believe that these numbers were studied by Leonardo de Pisa, known as Leonardo Fibonacci, which, however, has not been verified by any work in the literatureso far.

The Leonardo sequence carries $L e_{n}=L e_{n-1}+L e_{n-2}+1, n \geq 2$ as its recurrence relation and has $L e_{0}=L e_{1}=1$ as its initial terms. Also, Catarino and Borges (2019) present another recurrence that satisfies Leonardo numbers, given by: $L e_{n}=2 L e_{n-1}-$ $L e_{n-3}, n \geq 3$, where the initial terms were kept. It is also possible to establish a relationship between Leonardo numbers and Fibonacci numbers, presented by: $L e_{n}=2 F_{n+1}-1, n \geq 0$.

On the other hand, Harman (1981) explores two-dimensional relationships or Gaussian numbers, denoted $G(n, m)=a+b i$ as $a, b \in \mathbb{Z}$ and $i^{2}=-1$. Thus, Oliveira (2018), Oliveira et al. (2017) define two- and three-dimensional identities for Fibonacci numbers in complex form and some of their inherent properties. Also, Vieira et al. (2019a) present the two-dimensional relationship of Leonardo numbers and their inherent identities.

Briefly, associating Leonardo sequence with two-dimensional relationships, we have the elements of type $a+b i$, in which $a$ and $b$ are the terms of Leonardo sequence, adapting to the general notation described in the form $L e_{n}=2 L e_{n-1}-L e_{n-3}$, for an index $n \in \mathbb{N}$, highlighting the imaginary unit $i$, in which $i^{2}=-1$, we can glimpse this representation as a Leonardo complex number. 
Thus, we have some properties derived from the recurrence of the one-dimensional Leonardo sequence $(\operatorname{Le}(n)=2 L e(n-$ $1)-\operatorname{Le}(n-3))$. With the following initial values defined: $\operatorname{Le}(0,0)=\operatorname{Le}(1,0)=1, \operatorname{Le}(0,1)=\operatorname{Le}(1,1)=1+i, \operatorname{Le}(0)=\operatorname{Le}(1)=$ $1, \operatorname{Le}(2)=3, \operatorname{Le}(2,0)=3, \operatorname{Le}(1,2)=3+i$ and $\operatorname{Le}(2,1)=3+2 i$, we have that for the two integers $, m, n \in \mathbb{N}$, satisfy the twodimensional recurring relations:

$$
\left\{\begin{array}{l}
L e(n+1, m)=2 L e(n, m)-\operatorname{Le}(n-2, m) \\
L e(n, m+1)=2 L e(n, m)-L e(n, m-2)
\end{array}\right.
$$

Thus, the numbers in the form $\operatorname{Le}(n, m)$ have the properties described by:

$L e(n, 0)=L e(n)$;

$L e(0, m)=L e(m)+\left(\frac{L e(m-1)+1}{2}\right) i$.

Hence, to explore and investigate this mathematical content, we created a problem situation of this concept, supported by the TDS, to stimulate the students' intuitive and investigative side.

\section{A PRIORI CONCEPTION AND ANALYSIS OF DIDACTIC SITUATIONS}

In the conception phase, the didactic variable that will be used in this research is established, thus, the microdidactic variable, as we intend that there is an interaction between the mathematical content and the problem situation posed. The didactical conception in this work displays the complexification process of the Leonardo sequence, transforming it into content to be addressed in a class of initial teacher education, since, for the resolution to this situation to be achieved, prior mathematical knowledge is necessary, as the principle of mathematical induction will be used.

On the other hand, in the a priori analysis of the didactic situation, we intend to predict the possible behaviour of students in the action, formulation, validation, and institutionalisation phases. With this, some didactic hypotheses about the problem situation presented were raised.

Problem situation: Establish properties for $L e(1, m)$ and $L e(n, 1)$ for two-dimensional Leonardo numbers. Demonstrate them.

In this first problem situation, in the action situation, students must use the recurrences previously given and they must realise that to find $\operatorname{Le}(n, 1)$, they will use the recurrence $\operatorname{Le}(n+1, m)=2 \operatorname{Le}(n, m)-L e(n-2, m)$, because they will fix $m=1$ and vary $n$. Similarly, to find $\operatorname{Le}(1, m)$ the second recurrence will be used, in which they will fix $n=1$ and vary $m$.

During the formulation, students must use the terms previously found, and, from there, students must intuitively find a pattern between the terms found and will present the requested property. Thus, students should present that $\operatorname{Le}(1, m)=\operatorname{Le}(m)+$ $\left(\frac{L e(m-1)+1}{2}\right) i$ and $L e(n, 1)=L e(n)+\left(\frac{L e(n)+1}{2}\right) i$.

In the validation phase, students must show, by the mathematical induction method on $n$ and on $m$, fixing the value of the natural number, that the property found is valid for 1 , assume that it is valid for $k$ and show that it is valid for every $k+1$. With this, the property will be demonstrated mathematically.

Finally, in institutionalisation, the teacher resumes the didactical situation and verifies the students' resolutions and reveals that from two distinct mathematical contents, it is possible to make a link between them and generate new content to be explored, initiating the complexification process of the Leonardo sequence, from the insertion of the imaginary unit.

\section{EXPERIMENTATION}

The problem situation created is applied during the experimentation phase. This phase was carried out in a class of History of Mathematics of the mathematics teaching degree course of the Federal Institute of Ceará, with the participation of five prospective teachers.

The activity was carried out via Google Meet, due to the context of the coronavirus (COVID-19) pandemic. Thus, the classes and activities were planned and applied virtually, and the students were given a commitment term that ensured their privacy. We also requested the students' consent to record the classes. Besides Google Meet, the teacher provided his WhatsApp number so that students could send him the answers to the situation in a higher quality.

The remote application is not harmful to the research because discussions about the situation applied were raised with the participants' collaboration.

\section{A POSTERIORI ANALYSIS AND INTERNAL VALIDATION}

In this stage, the students' situations are analysed and evaluated, and the Leonardo sequence's complexification process is investigated. The TDS was used as a teaching theory, and discussions of this situation were held. After the analysis, the results are validated by comparing these results and the data in the a priori analysis. This comparison will validate or refute the results.

In the problem situation executed, the objective is to establish properties for $L e(1, m)$ and $L e(n, 1)$. With this, we presented two recurrences that satisfy Leonardo's two-dimensional and its initial terms, providing students with theoretical support, facilitating the resolution of the situation. Thus, we can see that in Figure 1, student A chose the recurrence $\operatorname{Le}(n, m+1)=$ 


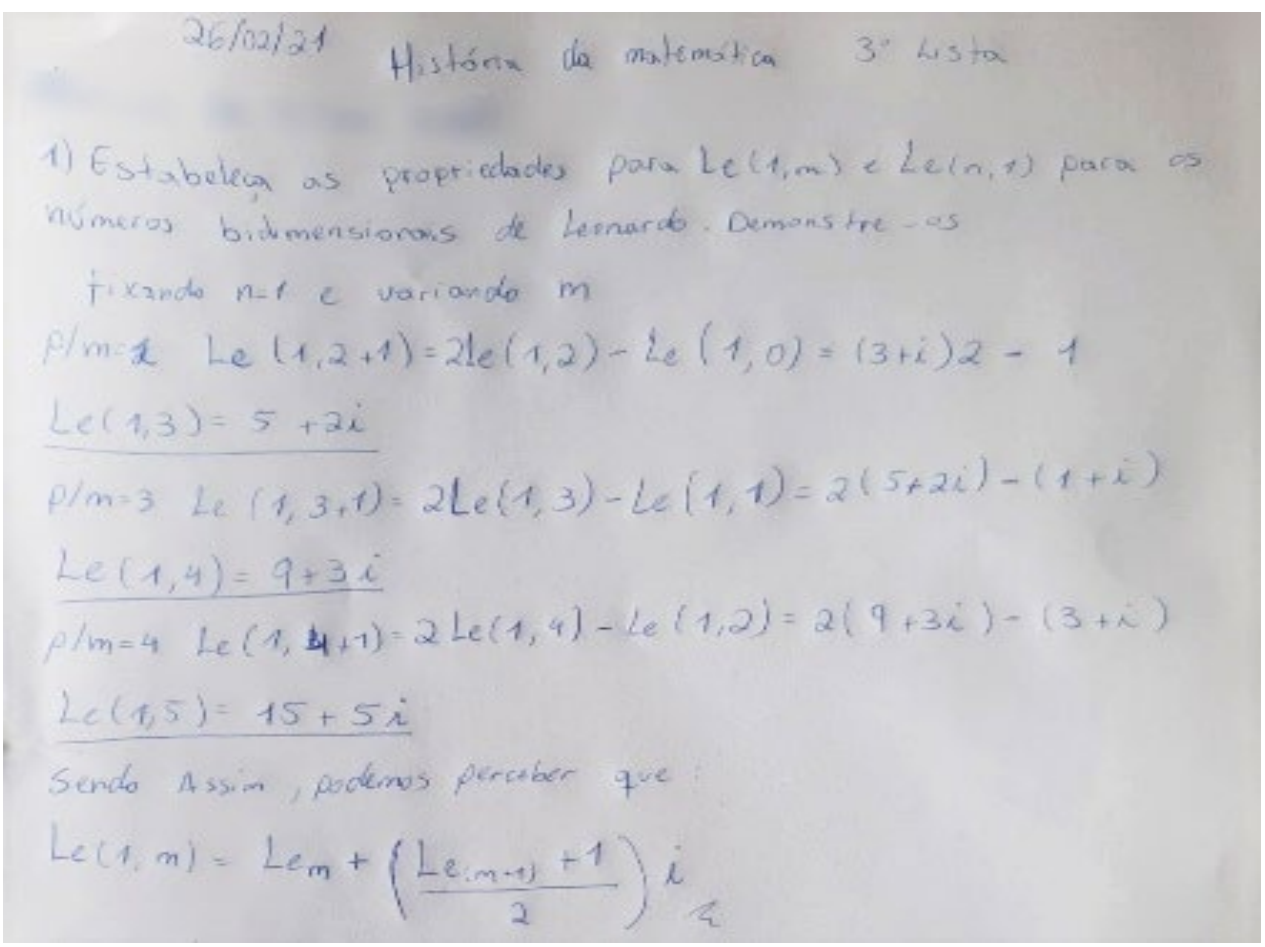

Figure 1. Action and formulation phase by student A. (Survey data)

$2 L e(n, m)-L e(n, m-2)$ to use, fixed $n=1$ and varied $m$. Then, the student perceived a relationship between the terms found and formalised the $\operatorname{Le}(1, m)$.

On the other hand, student B found the same terms as student A when fixing $n=1$ and varying $m$, but when trying to find a pattern between the terms, this student showed that the terms found, together with the imaginary unit $i$, are the numbers of the Fibonacci sequence, as we can see marked in red in Figure 2. This student reported that he perceived Fibonacci terms since Leonardo sequence is very similar to Fibonacci's. However, Student B could not present $L e(1, m)$ only in function of Leonardo terms.

In Figure 3, to find $\operatorname{Le}(n, 1)$, student A, like before, used the recurrence $\operatorname{Le}(n+1, m)=2 \operatorname{Le}(n, m)-\operatorname{Le}(n-2, m)$, in which he fixed $m=1$ and varied $n$.

In this way, he found a relationship between the terms and found what was proposed. Giving continuity to the question posed, we can see, in Figure 4, that student A uses the principle of mathematical induction to validate the property found. At first, in the first stage of the induction, the student tested whether the property was valid for $m=1$, after which he assumed that it was valid for $m=k$ and verified whether it was valid for $k+1$. During the verification, the student reported his difficulties to develop the accounts in class, when student $C$ realised that by placing in evidence some terms, they could find the recurrence of Leonardo sequence and thus make a replacement and validate the property for $k+1$. So, this proved that the property the students had found is valid.

During the explanation of student A to his mates of how he performed the induction method, student B raised the following question: "if in the first stage of the induction we used $m=0$, would the property still be valid?" The question arose because, in this case, the term $L e_{-1}$ appears, so the teacher encouraged the student to find the negative terms of the Leonardo sequence, finding $L e_{-1}=-1$ and by replacing it in the equation, the student was able to validate the property.

Also, like what was done before, the student used the inductive method to demonstrate $\operatorname{Le}(n, 1)$, as we can see in Figure 5. 


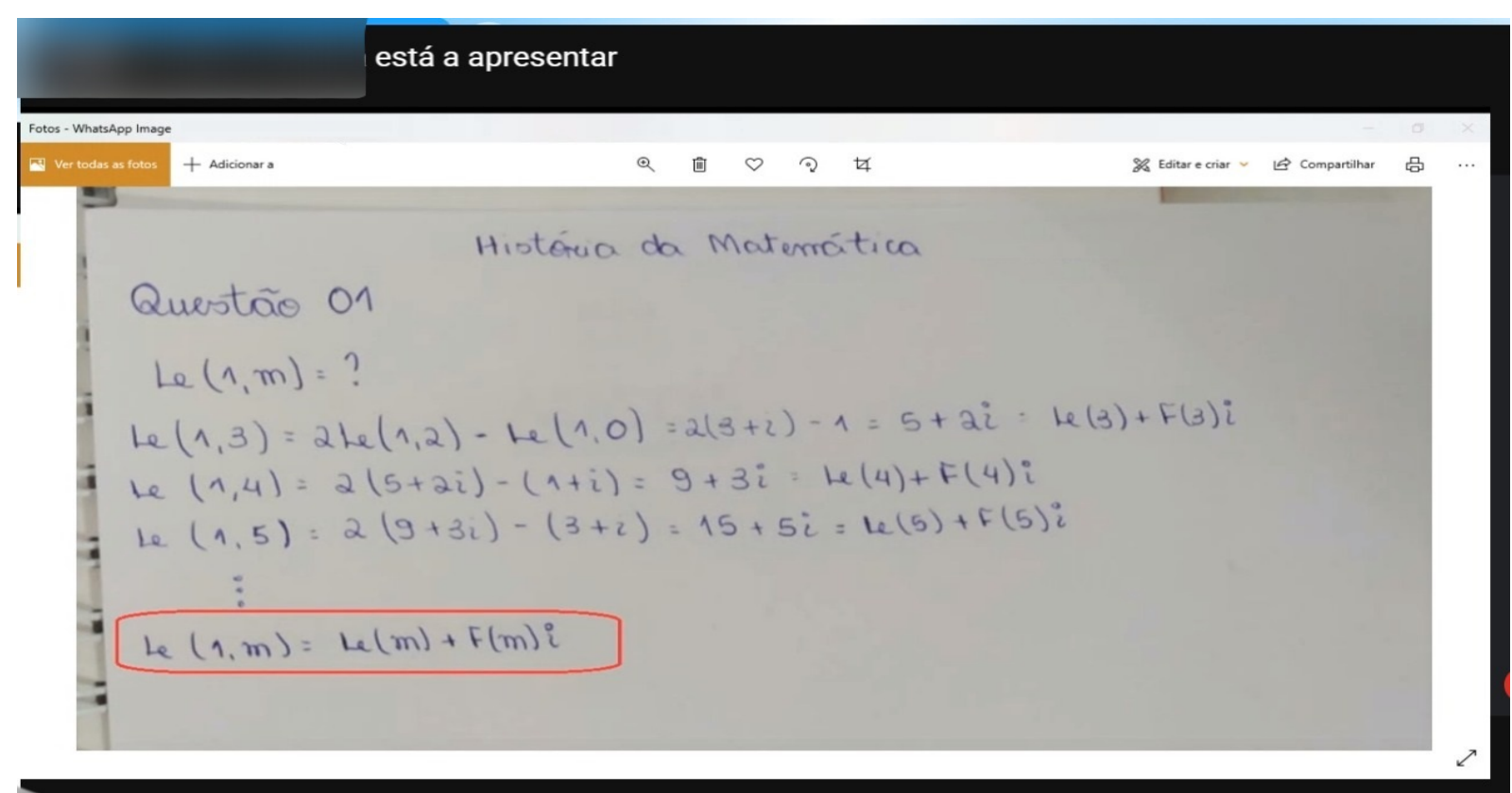

Figure 2. Action and formulation phase by student B via Google Meet. (Survey data)

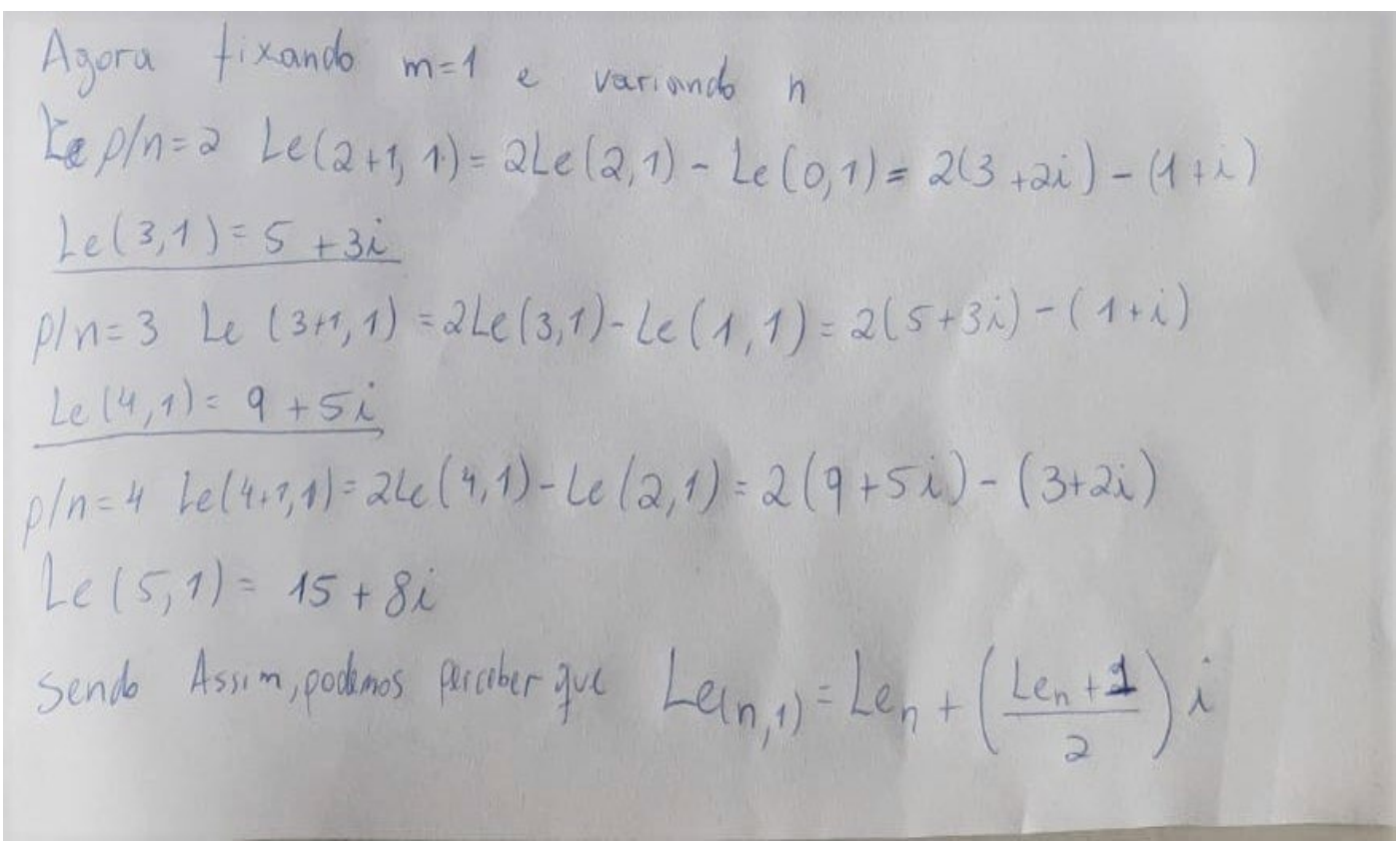

Figure 3. Action and formulation phase by student A. (Survey data) 


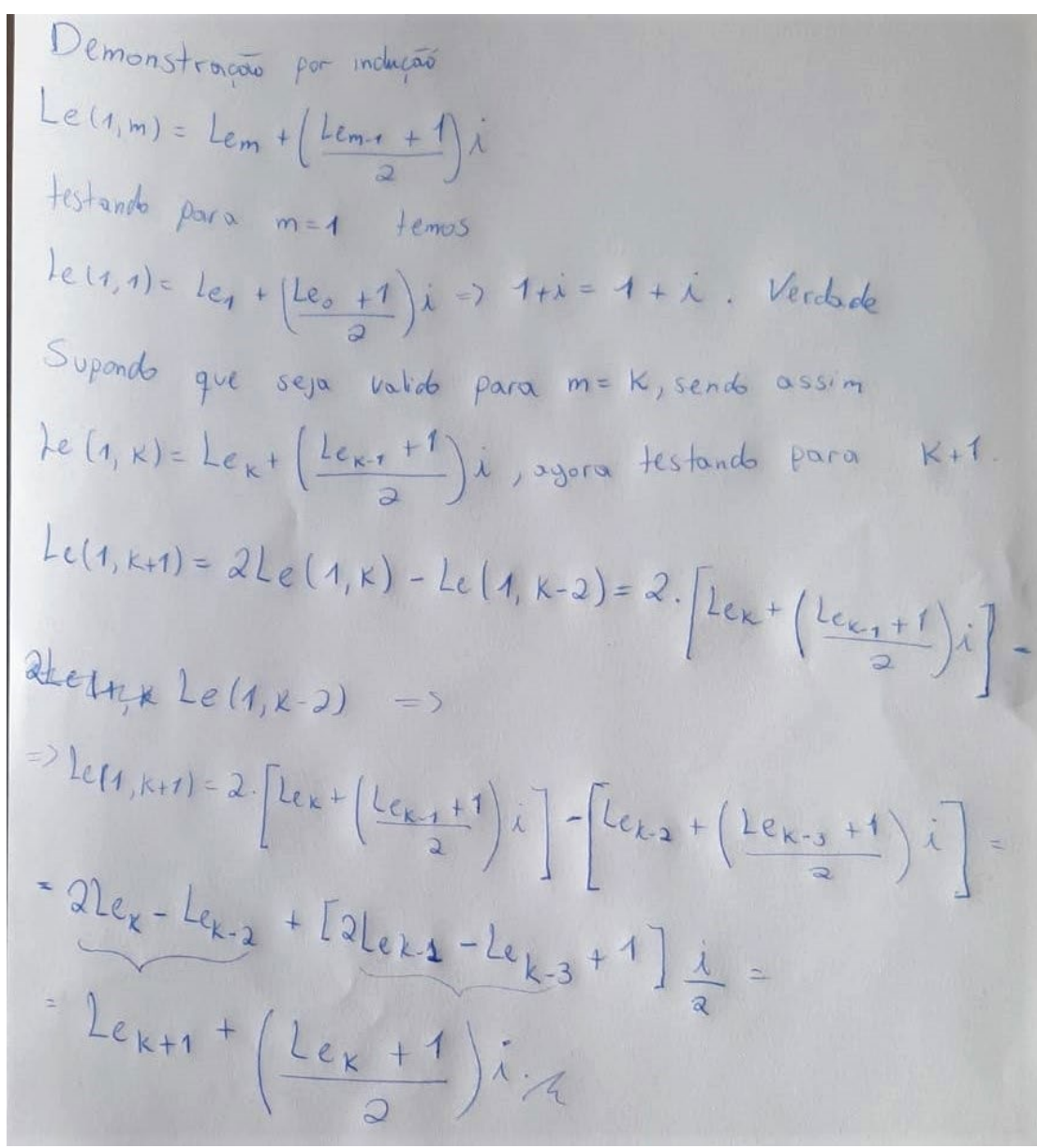

Figure 4. Validation phase by student A. (Survey data)

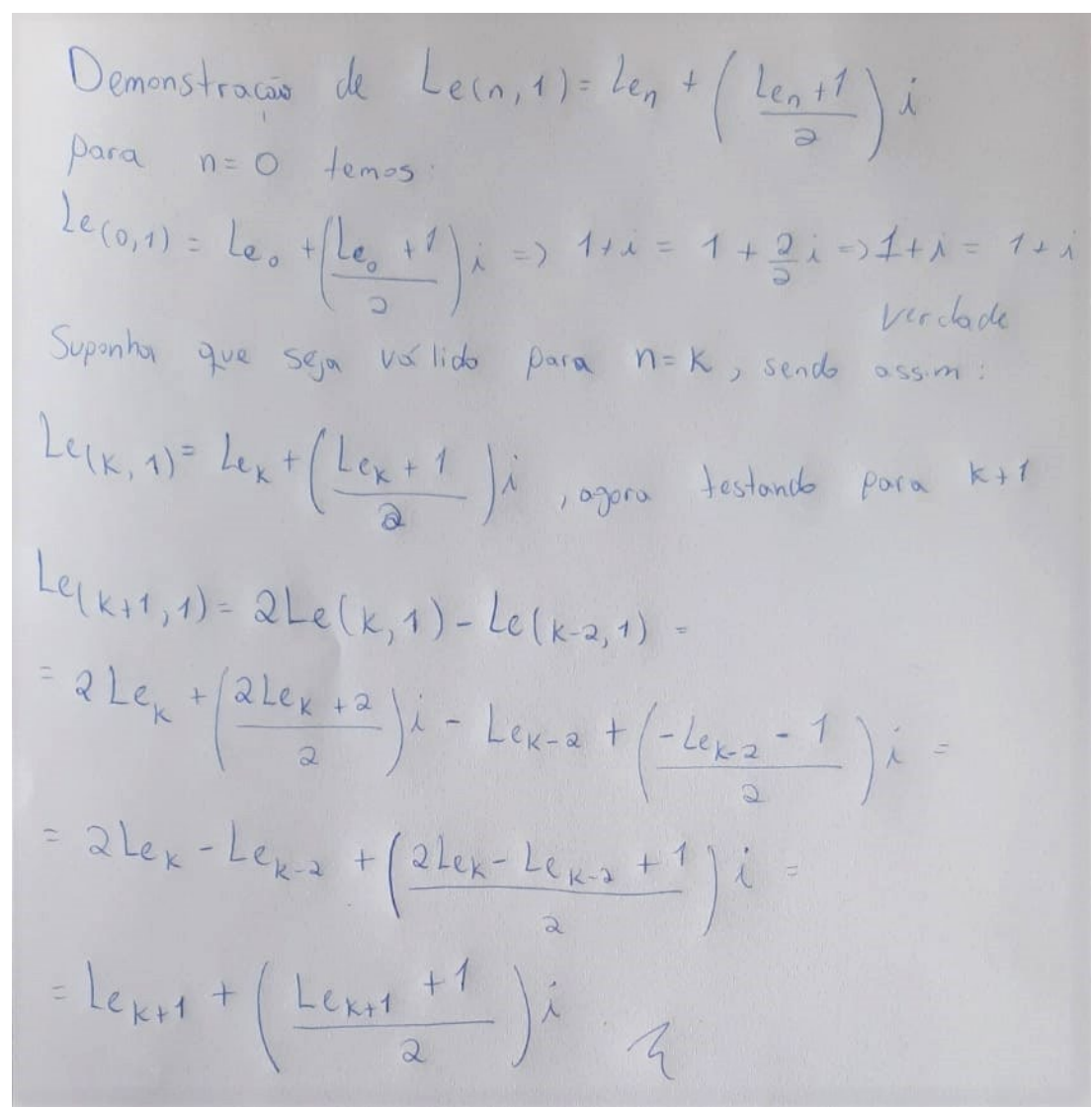

Figure 5. Validation phase by student A. (Survey data) 
With this, the teacher carried out the institutionalisation, analysing the students' responses, where it was possible to indicate and explain the properties constructed. In the problem situation posed, it was possible to formalise the Leonardo sequence's complexification from the insertion of the imaginary unit $i$.

Finally, internal validation was performed, i.e., only the results obtained from the analysis of collected data and the group of students involved were analysed. In this validation phase, the data of what was predicted in the a priori analysis and what was obtained in the a posteriori analysis were compared. From this confrontation, we perceived that the students could construct the complexification process of the Leonardo sequence, presenting properties of two-dimensional numbers of this sequence. With this, it was possible to affirm the validity of the main objective of the research.

\section{CONCLUSION}

This research is an excerpt from a research work developed in the Postgraduate Programme in Science and Mathematics Teaching of the Federal Institute of Cerará, Fortaleza campus, approved by the Research Ethics Committee (Opinion n. 4.141.910), which investigates a process of hybridisation and hypercomplexification of recursive linear sequences, specifying the Leonardo sequence and evidencing elements of didactic, cognitive, and epistemological order around the epistemic-mathematic field. The investigation was carried out in the discipline of History of Mathematics for a class of initial teacher education, remotely, via Google Meet, due to the COVID-19 pandemic.

We first conducted a bibliographical survey around didactic engineering and the theory of didactical situations, and also around the Leonardo sequence and the completion of recursive linear sequence. After defining the mathematical-epistemic field and the methodology, we applied the problem situation, a phase called experimentation predicted by the DE, where the mathematical properties were formulated and explored, and later, we validated the research results, concluding that although the students presented difficulties at the beginning of the mathematical induction, we could validate the situation and affirm that the objective of the research was achieved.

In this research, we could understand the Leonardo sequence' evolutionary process from its one-dimensional model to the complexification of its numbers, presenting properties of the two-dimensional model of this sequence, with the insertion of the imaginary unit. We conclude that the students were the protagonists of their knowledge around the complexification of the Leonardo sequence.

For future work, it is possible to work the properties of this sequence in its three-dimensional and the $n$-dimensional form, based on teaching situations. These studies can also be carried out in other institutions, to enable external validation.

Author contributions: All authors have sufficiently contributed to the study, and agreed with the results and conclusions.

Funding: The research development part of Brazil was financially supported by the National Council for Scientific and Technological Development (CNPq) and the Coordination for the Improvement of Higher Education Personnel (CAPES). National funds fund the development of the research in Portugal through the Foundation for Science and Technology. I. P (FCT), under project UID/CED/00194/2020.

Declaration of interest: No conflict of interest is declared by authors.

\section{REFERENCES}

Almouloud, S. A. (2007). Fundamentos da didática da matemática [Fundamentals of mathematics didactics]. Editora UFPR.

Almouloud, S. A., \& Silva, M. J. (2012). Engenharia didática: evolução e diversidade [Didactic engineering: evolution and diversity]. Revemat: Revista Eletrônica de Educação Matemática, 7(2), 22-52. https://doi.org/10.5007/1981-1322.2012v7n2p22

Almouloud, S., \& Coutinho, C. Q. S. (2008). Engenharia Didática: características e seus usos em trabalhos apresentados no GT-19 / ANPEd 1 [Didactic Engineering: characteristics and its uses in works presented in GT-19 / ANPEd 1]. REVEMAT - Revista Eletrônica de Educação Matemática, 3(1), 62-77. https://doi.org/10.5007/1981-1322.2008v3n1p62

Alves, F. R. V., \& Dias, M. A. (2017). Formação de professores de matemática: um contributo da engenharia didática [Mathematics teacher training: a contribution from didactic engineering]. REVEMAT, 12(2), 192-209. https://doi.org/10.5007/19811322.2017v12n2p192

Alves, F. R. V., \& Vieira, R. P. M. (2020). The Newton fractal's Leonardo sequence study with the Google Colab. International Electronic Journal of Mathematics Education, 15(2), 1-9. https://doi.org/10.29333/iejme/6440

Alves, F. R. V., Catarino, P. M., Vieira, R. P. M., \& Mangueira, M. C. dos S. (2020). Teaching recurrent sequences in Brazil using historical facts and graphical illustrations. Acta Didactica Naposcencia, 13(1), 1-25. https://doi.org/10.24193/adn.13.1.9

Alves, F. R. V., Vieira, R. P. M., da Silva, J. G. A., \& Mangueira, M. C. S. (2019). Engenharia Didática para o ensino da Sequência de Padovan: um estudo da extensão para o campo dos números inteiros. In F. A. M. F. Gonçalves (Ed.), Ensino de ciências e educação matemática 3. Atena Editora. https://doi.org/10.22533/at.ed.0901922112

Artigue, M. (1995). Ingeniería didáctica en educación matemática. Un esquema para la investigación y la innovación en la enseñanza y el aprendizaje de las matemáticas [Didactic engineering in mathematics education. An Outline for Research and Innovation in Mathematics Teaching and Learning]. Una empresa docente \& Grupo Editorial Iberoamérica. 
Brousseau, G. (1986). La relation didactique: le milieu [The didatic relationship: The environment]. Actes de la IVème Ecole d'Eté, 54-68.

Catarino, P. M., \& Borges, A. (2019). On Leonardo numbers. Acta Mathematica Universitatis Comenianae, 89(1), 75-86.

Harman, C. (1981). Complex Fibonacci numbers. The Fibonacci Quarterly, 19(1), 82-86.

Oliveira, R. d., Alves, F. R. V., \& Paiva, R. (2017). Identidades bi e tridimensionais para os números de Fibonacci na forma complexa [Two- and three-dimensional identities for Fibonacci numbers in complex form]. Revista Eletrônica Paulista de Matemática, 11, 91-106. https://doi.org/10.21167/cqdvol11ic201723169664rrofrvarebp91106

Oliveira, R. R. de, Andrade, M. H. De, \& Alves, F. R. V. (2018). Função geradora e equação característica no contexto de investigação histórica do modelo de Fibonacci fundamentada na Engenharia Didática [Generating function and characteristic equation in the context of historical investigation of the Fibonacci model based on Didactic Engineering]. Boletim Cearense de Educação e História da Matemática, 5(41), 41-50. https://doi.org/10.30938/bocehm.v5i14.30

Oliveira, R. R. de. (2018). Engenharia didática sobre o modelo de complexificação da sequência generalizada de Fibonacci: Relações recorrentes $n$-dimensionais e representações polinomiais e matriciais [Didactic engineering on the generalized Fibonacci sequence complexification model: $n$-dimensional recurrent relations and polynomial and matrix representations] [Master's dissertation in Science and Mathematics Teaching], Instituto Federal de Educação, Ciência e Tecnologia do Estado do Ceará, Fortaleza.

Pommer, W. M. (2013). A Engenharia Didática em sala de aula: Elementos básicos e uma ilustração envolvendo as Equações Diofantinas Lineares [Didactic Engineering in the classroom: Basic elements and an illustration involving Linear Diophantine Equations]. S. N.

Rodrigues, G. R., \& Alves, F. J. C. (2019). Avaliação do uso de uma sequência didática no ensino de matrizes através da programação em blocos por um grupo focal [Evaluation of the use of a didactic sequence in the teaching of matrices through programming in blocks by a focus group]. Revista de Estudos e Pesquisas sobre o Ensino Tecnológico, 5(12), 30-50. https://doi.org/10.31417/educitec.v5i12.758

Shannon, A. G. (2019). A note on generalized Leonardo numbers. Notes on Number Theory and Discrete Mathematics, 25(3), $97-101$. https://doi.org/10.7546/nntdm.2019.25.3.97-101

Slisko, J. (2020). Lo que pueden aprender los estudiantes a partir del error de Fibonacci al resolver el problema "El león en el pozo" [What Students Can Learn from the Fibonacci Error in Solving the "Lion in the Well" Problem]. Góndola, enseñanza y aprendizaje de las ciencias, 15(2), 216-238. https://doi.org/10.14483/23464712.16041

Vieira, R. P. M., Alves, F. R. V., \& Catarino, P. M. M. C. (2019a). Relações bidimensionais e identidades da sequência de Leonardo [Two-dimensional relationships and identities in the Leonardo sequence]. Revista Sergipana de Matemática e Educação Matemática, 4(2), 156-173. https://doi.org/10.34179/revisem.v4i2.11863

Vieira, R. P. M., Mangueira, M. C. dos S., Alves, F. R. V., \& Catarino, P. M. M. C. (2020). A forma matricial dos números de Leonardo [The matrix form of Leonardo's numbers]. Ciência e Natura, 42, 1-13. https://doi.org/10.5902/2179460X41839

Vieira, R. P., Alves, F. R., \& Catarino, P. M. (2019b). Uma exploração da sequência de padovan num curso de licenciatura em matemática [An exploration of the padovan sequence in an undergraduate mathematics course]. Indagatio Didactica, 11(4), 261-279. https://doi.org/10.34624/id.v11i4.10641 